\title{
Citizen, interrupted: the 2011 English riots from a psychosocial perspective
}

\author{
G. Aiello and C. M. Pariante* \\ Department of Psychological Medicine, King's College London, Institute of Psychiatry, London, UK
}

Aims. This is a contribution to the debate over the 2011 English riots from a psychosocial perspective.

Methods. We compare the impulsive and 'mindless' behaviour of rioters with the impulsive, violent and contradictory behaviour of people affected by severe personality disorders.

Results. We propose that the lack of a sense of social identity and of mentalization skills is a common feature of the two conditions - the lack of social identity, leading to frustration and anger, coupled with a lack of mentalization, leading to the impulsive and violent expression. Furthermore, we highlight the confusing impact that the social marginalization and consumerism can have on young generations from lower classes in cities from the Western world.

Conclusions. By building a parallel with the therapeutic intervention offered to severe personality disorders, we speculate on how the community, by modifying its communication's style and actively intervene in deprived socio-economic contexts, could inspire more confidence, trust and sense of belonging in its marginalized members.

Received 5 February 2012; Revised 3 May 2012; Accepted 10 May 2012; First published online 18 July 2012

Key words: mentalization, social contagion, social identity, violence.

\section{The facts}

From 6 to 10 August 2011, riots took place in England, originally beginning in Tottenham, North London, before spreading to other areas of London, and then to other major cities and towns across the country. Widespread rioting, arson and looting occurred, along with injuries to the public and police, and the death of five members of the public.

According to a Ministry of Justice and Home Office background analysis (Travis, 2011), this was mainly a spontaneous movement where criminals and gang members did not play a pivotal role. Those arrested during the riots mainly came from deprived areas and had the poorest educational backgrounds. More than two-thirds of the young people involved were classed as having special educational needs, and one-third had been excluded from school in the previous year. More than $42 \%$ received free school meals. The analysis of the ethnic backgrounds of those brought before the courts for riot-related offences

* Address for correspondence: Carmine M. Pariante MD, MRCPsych, PhD, Professor in Biological Psychiatry and Head of the Sections of Perinatal, Psychiatry and Stress, Psychiatry and Immunology, Department of Psychological Medicine, Institute of Psychiatry, Kings College London, Room 2-055, The James Black Centre, 125 Coldharbour Lane, London SE5 9NU, UK.

(Email: carmine.pariante@kcl.ac.uk) varied significantly from the local population, with $42 \%$ of defendants white and $46 \%$ black. Only $7 \%$ were Asian (Travis, 2011).

\section{The debate}

The debate over the English riots dominated the most important newspapers and TV programs in the United Kingdom over the following months. Two main positions emerged: on the one hand, the riots were interpreted as the extreme expression of the greed and moral blight prevalent in the wider society (Sparrow, 2011); on the other hand, the riots were interpreted as a form of protest to express frustration for a chronic condition of poverty, lack of opportunity and social marginalization (Batmanghelidjh, 2011; Cavanagh, 2011). However, we propose that both these interpretations fail to fully explain this phenomenon, and that, several months after the events took place, some crucial questions still wait for a clear answer (Delamothe, 2011). Why did rioters set fire to their own communities, and why did they loot consumerist goods - plasma TVs, 'branded' fashionable electronics and expensive shoes? Some authors have tried to answer these challenging questions using a psychobiological perspective, highlighting the relationship between antisocial behaviour and the long-lasting effects of childhood trauma on brain functioning 
(Misselbrook, 2011). We intend to contribute to this debate by proposing a broader theoretical formulation of these terrible events, from a psychosocial point of view. We believe that psychiatrists, as 'specialists of the mind', may help understanding what has been repeatedly described as 'mindless' violence. Indeed, psychiatrists, in their everyday practice, have a nonjudgemental attitude towards the unusual experiences and behaviours of their patients, without ever condemning them or colluding with them. Here, we use this same non-judgemental attitude in trying to understand these events. Needless to say, understanding does not mean justifying.

\section{Did the rioters lack mentalization?}

We would like to propose that the rioters were experiencing what has been defined, within the psychopathology context, as 'lack of mentalization' (Fonagy, 2000): the lack of ability to identify one's own state of mind, to give them a name and to assign them significance. Feelings and intentions are perceived, therefore, only as physical sensations. When such sensations become emotionally overloading, they often lead to an unbearable sense of physical restlessness, and are subsequently 'evacuated' through an 'act' of physical violence, either against self or others. Although the mentalization theory has been applied in recent years also to other psychiatric conditions, such autism and schizophrenia, in this paper we specifically refer to its original use in relation to personality disorders.

Some psychiatrists (Paris, 1997) have suggested that the lives of patients affected by severe personality disorders in modern societies are characterized by an attempt to achieve a sense of 'social identity' and to define their role in the community, in relationship with friends, a social group, a job and a family. Unfortunately, the struggle between the need to form attachment and the sense of alienation and disconnectedness, typical of personality disorders, often jeopardizes the chances to achieve a meaningful and satisfactory relationship with the community. The frustration at the repeated failures to reach this aim is then expressed in ways that are confused, impulsive, contradictory and violent. This in turn creates a vicious circle, as the people in the community cannot understand or empathize with these seemingly impulsive and 'mindless' acts of violence. Ultimately, patients' sense of failure to define their social identity grows deeper.

Although we accept that it is speculative to extrapolate a psychopathological construct to group behaviour, we believe that, used metaphorically as in this editorial, it helps to conceptualize the confused and fragmented expression of protest and violence during the 2011 riots. However, from a clinical point of view, it is of interest that the recent UK survey showing abnormal personality traits are incrementally associated with younger age, childhood institutional care, expulsion from school, contacts with the criminal justice system and economic inactivity (Yang et al. 2010), that is, to some of the social features that were present in the rioters.

We would like to further propose that both these mechanisms were operating on the nights of riots: a lack of social identity, leading to frustration and anger, coupled with a lack of mentalization, leading to the violent expression.

\section{At the margins of society}

Aristotle (1998) stated that in Politics 'Anthropos zoon politicon' - man is by nature a social animal. In order to define his identity, the human being needs to play an active role in his community, and to feel part of it. The more this need of social identity is neglected, the less social and civilized the human being becomes.

Often modern riots are compared with past and more cogent, politicized forms of protest, such as those of the socialist movements, usually to highlight how modern riots lack political argumentation. An important defining feature of socialist protests, highlighted by Marx (1970) was that participants were able to identify themselves as part of a working class with an active role in the community. They represented a cohesive social group, able to argue a political position at every level, from the political discussion to the street protest, and to express clearly their needs and their requests to the rest of the society.

In the past 10 years, we have witnessed several riots in some of the major European cities, like Paris in 2005 and Brussels in 2006, just to quote the most violent. Although the rioters themselves were unable to make a coherent political statement, the articles and reports on the most important journals at that time gave a clear social interpretation of these events. Specifically, both in Paris and Brussels the racial and economical problems were clearly identified as triggers of the violence, and the looting, when present, was an epiphenomenon, a secondary effect of the general unrest (Goodman, 2011). Reporters and commentators related the violence to a context of discrimination and marginalization of the North-African community in France and Belgium, and the violence was seen as representing, at least from a communicative point of view, a clear expression of rage and frustration because of the lack of opportunities within the North-African 
community in those countries (Smith, 2005). Therefore, even if the rioters themselves did not have constructive proposals and were not interested in a dialogue with the community, they were seen by commentators to share at least elementary form of 'social identity'.

In contrast, the peculiarity of the English riots lies in their confused and disorganized nature, and in the absence of any attempt not only from the rioters to express a common social message but also from the commentators to identify one. The riots started as a social protest against the police, but ended up as a spontaneous, collective robbery - a highly disarticulated form of social protest with a message to society that was very contradictory and difficult to decrypt. We would like to propose that this indicates a failure of the English rioters to see themselves as a social group, and as having a 'social identity'. Perhaps because of a lack of ideological background, these young people - living in areas of high unemployment and in a country with the lowest level of social mobility in Europe (OECD, 2010) fail to understand their position in society, in relation to either the people around them or to their own past. Additionally, we would like to propose that the stealing of consumerist goods - shoes, clothes, electronics and mobile phones - constitute an attempt to obtain such a social identity.

\section{Was this social contagion?}

Historically, social contagion, through uncritical acceptance of rumours, unverified information and persecutory interpretations of facts, has often unleashed acts of irrational mass behaviours, at times extremely cruel and violent (Mackay, 2008); however, it is difficult to fully explain these riots as the effect of social contagion. The 'convergence' theory proposes that shared motivations cause individuals with similar predispositions, attitudes and personality traits to 'converge' and thus to fuel one another's behaviours (Turner \& Killian, 1987). Some anthropologists have also shown, in relation to previous riots, that an atmosphere of cultural resentment and victimization is often present in the social group responsible for the violence, week or months before the upheaval (Veena, 1998). Such shared resentment increases the sense of identity of the group which than perceives any offence perpetrated to the single as an offence to the group (Redmond, 2007). However, the English riot quickly lost the identity of a 'collective protest' in response to the death of a black man shot by police. The move to Brixton on the second night may represent an attempt of the rioters, perhaps conscious and perhaps not, to keep that identity of a collective protest by connecting symbolically to the 1981 Brixton riots. However, even this attempt eventually fails, and eventually the riots spread throughout England in the form of mere looting and violence. In our view, therefore, in the absence of a group identity, the social contagion has the effect to consolidate not a protest of a group against another, but rather the conflict between the rioters and their own communities, from where they feel excluded.

\section{Consumerism as a new social identity}

In the 1960s, the philosopher Marcuse (Marcuse, 1991) believed that the most marginalized members of the American society (such as immigrants and students) were the last revolutionary force, able to counteract, and propose alternatives to a consumerist society. The English riots highlight, to the contrary, that the most marginalized members of the society aspire to consumerist goods: to the flamboyant ostentation of branded accessories - the 'bling-bling' of the hip-hop culture (Hauser \& Lownes, 2005). This creates a strong sense of confusion: on the one hand, the 'socially excluded' would like to share the goods (the 'symbols' and the 'idols' of the community) and, on the other hand, they know that they will never be part of the community that can afford those goods. This desire, constantly unfulfilled, leads to a sense of frustration and resentment. On this occasion, unable to 'mentalize' these emotions, people just turn into violent looters.

Interestingly, riots with a prominent looting character have occurred in England since the 19th century, and the tendency to use commodities as means of social identification is probably as old as the industrial revolution in England. As discussed in The Guardian (Reinke-Williams, 2011), British people have defined their identities by possession of manufactured commodities since at least the 18th century, and their desire for such products led to a series of 'consumer revolutions' that enabled Britain to lead the way in industrial production in the past, and in financial services today. In addition, the UK financial sector has grown considerably at the expenses of the manufacturing industry in the past decade (McKenzie, 2011), and modern finance is characterized by a progressive depersonalization of business and money, for example, because of the high-frequency trading entirely made by software. It would be important to further investigate the impact of such dramatic change on the individual's perception of value, work and social identity at every level of British society, and thus on the occurrence of violent events such as these riots (Jones, 2011). 


\section{What can we do?}

Similarly to the patients with personality disorders, who alienate the community that they so much long for, the 'socially excluded' destroy shops and steal goods in order to 'belong' - thus confirming that they are not part of the society, and increasing their social exclusion. How can we break this vicious circle?

John G. Gunderson (Gunderson \& Links, 2008), an expert on Borderline Personality Disorder, states that a good and successful therapist should show himself to the patient as 'present, involved and invulnerable'. We would like to propose that a healthy community, which tries to integrate its marginalized members, should try to show these same characteristics: 'present', meaning knowledgeable of the community members in difficulty; 'involved', meaning interested in helping the pursuit of the individual and social goals of the community; and 'invulnerable', meaning trustworthy, and morally coherent, in how we deliver on our promises of equal opportunities, personal development, social mobility and respect of the law.

Clearly these are complex cultural changes, involving not just single institutions but the society as a whole. However, practical steps can be delivered to improve social inclusion. For example, recent research in the USA has shown that social and psychological intervention can improve social belonging in ethnic minorities (Walton \& Cohen, 2007, 2011). The results of these studies show a positive association between increasing sense of belonging and improving academic achievements in the Afro-American population. Although these interventions are specifically focused on a student population, their results confirm the general hypothesis of this paper: that social belonging is a primary requirement to allow people to live a meaningful life in the community, and the major deterrent that a civilized and emancipated society can offer to prevent violence and riots.

\section{Conflict of Interest}

The authors have no conflict of interest in relationship to this paper. Professor Pariante has received speaker's fee from pharmaceutical companies such as Lilly and Innova Pharma Recordati.

\section{References}

Aristotle (1998). Politics. Translated by Sir Ernest Barker, R. F. Stalley. Oxford University Press: Oxford.

Batmanghelidjh C (2011). Caring costs - but so do riots. The Independent [online]. Retrieved 9 August 2011 from http://www.independent.co.uk/opinion/commentators /camila-batmanghelidjh-caring-costs-ndash-butso-do-riots-2333991.html.

Cavanagh M (2011). The riot blame game. The Independent [online]. Retrieved 15 August 2011 from http://blogs. independent.co.uk/2011/08/15/the-riot-blame-game/

Delamothe T (2011). Reading the riot acts. British Medical Journal 343, d7935.

Fonagy P (2000). Attachment and borderline personality disorder. Journal of American Psychoanalytic Association 48, 1129-1146.

Goodman JD (2011). Riots in London and Paris: Plus Ça Change? New York Times [online]. Retrieved 26 August 2011 from http://thelede.blogs.nytimes.com/2011/08/09/ plus-ca-change-riots-in-london-and-paris/.

Gunderson JG, Links PS (2008). Borderline Personality Disorder: A Clinical Guide, 2nd edn. American Psychiatric Press: Arlington, VA.

Hauser T, Lownes MC (2005). How bling-bling took over the ring. The Observer in The Guardian [online]. Retrieved 9 January 2005 from http://www.guardian.co.uk/sport/2005/ jan/09 /boxing.features.

Jones O (2011). Chavs: The Demonisation of the Working Class. Verso: London.

Mackay C (2008). Memories of Extraordinary Popular Delusions and the Madness of Crowds [1852]. Project Gutemberg EBook. http://www.gutenberg.org/files/24518/24518-h/ 24518-h.htm.

Marcuse E (1991). One Dimensional Man: Studies in the Ideology of Advanced Industrial Society, 2nd edn. Beacon Press: Boston, MA.

Marx K (1970). A Contribution to the Critique of Political Economy (ed. M. Dobb). International Publishers: New York.

McKenzie D (2011). Economic Contribution of UK Financial Service 2010. Annual Report. www.TheCityUK.com.

Misselbrook D (2011). What is it with kids these days? Journal of the Royal Society of Medicine 104, 392-393.

OECD (2010). Family Affair: Intergenerational Social Mobility across OECD Countries, II. 5. Economic Policy Reforms: Going For Growth. Retrieved 10 May 2012 from http://www.oecd. org/dataoecd/2/7/45002641.pdf.

Paris J (1997). Social Factors in Personality Disorders: A Biopsychosocial Approach to Etiology and Treatment. Cambridge University Press: Cambridge.

Redmond A (2007). Surfies versus westies: kinship, mateship and sexuality in the cronulla riot. Australian Journal of Anthropology 18, 336-350.

Reinke-Williams T (2011). What history can teach us about riots. Letters VA. Guardian [online]. Retrieved 14 August 2011 from http://www.guardian.co.uk/uk/2011/aug/14/ history-can-teach-us-riots.

Smith AD (2005). The Week Paris Burned. The Observer in Guardian [online]. Retrieved 6 October 2005 from http:// www.guardian.co.uk/world/2005/nov/06/france.focus.

Sparrow A (2011). David Cameron and Tony Blair clash over cause of riots. The Guardian [online]. Retrieved 6 October 2005 from http://www.guardian.co.uk/uk/2011/aug/21/ david-cameron-tony-blair-riots. 
Travis A (2011). UK riots analysis reveals gangs did not play pivotal role. The Guardian [online]. Retrieved 24 October 2011 from http://www.guardian.co.uk/uk/2011/oct/24/ riots-analysis-gangs-no-pivotal-role.

Turner RH, Killian LM (1987). Collective Behavior, 3rd edn. Prentice-Hall: New York.

Veena D (1998). Specificities: official narratives, rumour, and the social production of hate, social identities. Journal for the Study of Race, Nation and Culture 4, 109-130.
Walton GM, Cohen GL (2007). A question of belonging: race, social fit and achievement. Journal of Personality and Social Psychology 92, 82-96.

Walton GM, Cohen GL (2011). A brief social-belonging intervention improves academic and health outcomes of minority students. Science 331, 1447-1451.

Yang M, Void J, Tyrer P (2010). Personality pathology recorded by severity: national survey. British Journal of Psychiatry 197, A11. 